\section{Mir's problems could mean scale-down for science}

[WASHINGTON] The apparently successful restoration of power to the Mir space station last week (the power had not been fully restored as Nature went to press) means that onboard research should resume when a new American astronaut arrives on the station next month. But many experiments will be scaled down from their original design, and the long-term utility of Mir as a research platform is still in question.

Mission managers at the US National Aeronautics and Space Administration (NASA) say that 80 per cent of the original science objectives for the US/Russian research programme on Mir can still be met, even with the damaged Spektr module out of commission and power levels between half and three-quarters of what they were before a cargo ship crashed into Mir last June, damaging its solar arrays.

But John Charles of the National Aeronautics and Space Administration (NASA) Johnson Space Center, a mission scientist for the joint research programme, says that estimate is "a little bit generous".

In a revised research programme approved by both Russian and US investigators, some experimenters will have data collected less often to conserve power, while others will carry out only a subset of their planned investigations. Richard Zwierko, a shuttle-Mir mission planner at NASA headquarters in Washington DC, says the guiding philosophy behind the revised programme is that scientists would get the "minimum data" they need to obtain a useful result.

But several factors may further reduce the science output. The Kristall and Priroda laboratory modules, which have been shut down since June, may not be in full working order even if power is restored. The Mir crew has done its best to mop up condensation that formed inside the modules, but no one is certain if the moisture has damaged any equipment. Kristall and Priroda are used for microgravity and remote-sensing experiments.

Manpower is another concern. Dave Wolf, the US astronaut who will operate most of the experiments on Mir starting in September, will also be helping the Russian cosmonauts to repair the station. Wolf was a last-minute replacement for Wendy Lawrence; the switch was made when NASA decided to send an astronaut who could use the Russian space suit (Lawrence is too small). Wolf will take at least one spacewalk, which had not been planned for Lawrence's mission.

Wolf is not as familiar with the Mir experiments as Lawrence was, and is training furiously to catch up before his planned launch on 25 September. Biomedical researchers are

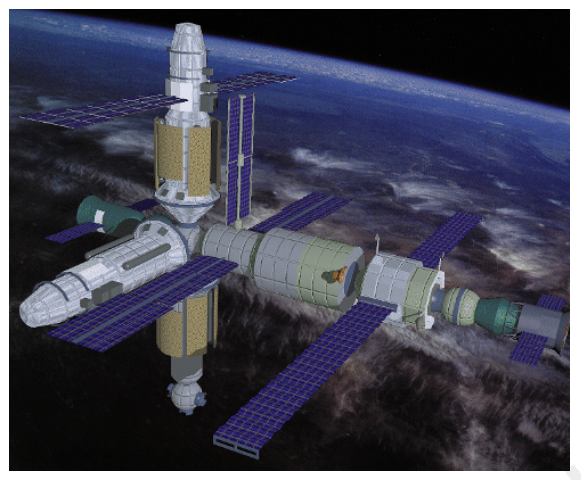

Science is a low priority on board Mir.

struggling to collect baseline data on the astronaut before he launches; this is critical to evaluating the physiological changes that occur in space. Without such data, some inflight experiments would be degraded.

Although Wolf is doing his best to accommodate the data collection, according to Charles, he has many competing demands on his time, including training for his spacewalk. As a result, says Charles, "there may still be holes" in the baseline data when he launches.

Based on recent experience on board Mir, Wolf can also expect regular computer failures and other hardware glitches on the ageing space station to require him to drop experiments and pick up a wrench. One nonNASA scientist participating in the shuttleMir programme says that, although "the astronauts do the best they can, science experiments are, for better or worse, at the bottom of the totem pole".

Charles says this has always been the case. Science, he says, was originally last on NASA's list of justifications for participating in the shuttle-Mir programme, after considerations such as gaining experience cooperating with the Russians and practising docking techniques. Indeed, NASA now uses "operational experience" as its primary rationale for continuing use of Mir - repair work and troubleshooting are seen as valuable in themselves, as they are similar to the kinds of maintenance that will be done on the International Space Station, construction of which is scheduled to begin next summer.

Russia, meanwhile, is reluctant to abandon Mir as long as its space engineers are persuaded that each new problem can be fixed. And the United States is loath to pull out unilaterally. So, barring a life-threatening emergency or major system failure, Mir is likely to keep flying, even with reduced capability.

According to Zwierko, even if onboard power never again gets above the 50 per cent level, some of the research programme will still be possible.

Tony Reichhardt

\section{State seeks independence in science policy}

[CANBERRA] Victoria has become the first of Australia's six states to develop a science and technology strategy that is independent of federal government policy.

The state premier, Jeff Kennett, has established a 19-member science, engineering and technology taskforce which he will co-chair with Adrienne Clarke, a plant cell biologist at the University of Melbourne. Clarke is a former chairman of the Commonwealth Scientific and Industrial Research Organization, and was recently made Lieutenant Governor of Victoria with a unique brief to promote science in the state (see Nature 387, 447; 1997).

As part of the drive, Victoria has also created the post of Principal Advisor for Science and Engineering, which has been taken by Margaret Britz, a food microbiologist from the Victoria University of Technology.

The commitment to developing an independent science policy contrasts with the approach of the federal government which has been criticized for indecisiveness over research during its 18 months in office.

Victoria is Australia's second most populous state and the most industrialized, with A $\$ 33$ billion (US $\$ 24$ billion) - or 30 per cent of its gross product - being generated from science and technology. Mark Birrell, the Victorian minister responsible for science, says his prime aim is to improve the business environment for research and development, a popular move among industry leaders who are openly frustrated by adverse actions of the federal government.

Although some new projects have been announced at modest levels of funding, the key to Victoria's future scientific success will be its capacity to finance substantial long-term programmes. All states have long felt frustrated by their dependence on taxes collected federally. Victoria has gone further than others in breaking away from subordination to Canberra by generating significant revenues from gambling in a vast new casino and from privatization of public utilities. Both of these moves are controversially promoted by Kennett.

In a statement launching the initiative, Kennett said its success "will depend on progressive Commonwealth reform of funding in areas such as taxation, research and development funding opportunities and intellectual property law". This is seen as a criticism of the federal government's recent science funding cuts. 